\title{
Climate Change Awareness and Its Effects on Crop Output in Oyo State
}

\author{
Olajide O. Adeola \\ Department of Agricultural Economics University of Ibadan, Ibadan Oyo State Nigeria
}

\begin{abstract}
Several adaptation strategies to climate change are being practiced by farmers but empirical information on the influence of such practices on crop output is not tested. This study examined farmer's response to climate change problems and the possible effect on crop output. The study area was Akinyele local government from which 100 farmers were randomly selected from 16 villages. Data were collected through oral interviews using questionnaires. The data were analyzed using descriptive and econometric tools. The results show that the decrease in output noticed by farmers was attributed to the changing conditions in the weather, the nature of the soil and soil conservation techniques. Farmers' perceptions on climate change are related to the negative effects such as crop destruction (26 percent) while some of them (42 percent) saw it as being 'supernatural'. The common response (43 percent) is to mitigate its effect by changing the planting date of crops while another 16 percent increased the use of chemicals on the farm. Other adaptation techniques include a decrease in the land area for crops such as maize and an increase of the land area under cassava. The econometric analysis shows that some of the adaptation techniques are having negative impacts on output. The research showed that farmers have varied understanding of climate change. There is a need for proper education and awareness on correct adaptation strategies as well as state support for proper adaptation of such techniques so that food supply will not be jeopardized.
\end{abstract}

Keywords: Farmers, Adaptation, Mitigation, Education, Awareness, Climate change, Perception

\section{Introduction}

Climate describes the characteristic conditions of the earth's lower surface atmosphere of a specific location while climate change is defined as the long term changes in average weather conditions. Agriculture is highly sensitive to climate because crop yield depend on whether conditions; both crop growth and development are temperature related (Kurukulasuriya and Mendelsohn 2006; Easterling et al, 2007). Climate change is a threat to agriculture and food security because of the loss in food production through crop failure and increase in disease and mortality rate of livestock (Akpodiaga \&Odjugo 2010). It also implies that it will indirectly increase poverty and sustain poor living standards if efforts are not made to produce food optimally while minimizing environmental degradation. Achieving such a balance will require definite actions at mitigating the effects of climate change or adapting to the situation.

During the last several decades, temperatures have increased across the globe, there has been an increased occurrence of heavy rainfall events and floods, and longer and more intense droughts in many regions of the world. These occurrences have often led to reduced crop yield levels and disruptions in agricultural production, especially in the most vulnerable and least prepared countries. Future development prognoses is that climate change impacts on agriculture are likely to increase due to greater climate variability, and increased frequency and intensity of extreme events from changes in average climatic conditions. If these occur, climatic changes would reshape the geography of agricultural land worldwide.

The situation can be averted by ensuring that small holder farmers practice the form and mix of adaptation strategies which will enhance food production and eventually lead to sustainable livelihood. The knowledge of farmers' current practices and their effect on food production and income generation will give background information to support farmer's efforts at adapting to climate change or mitigating its effects. This study is an attempt at examining such practices with the view of making policy recommendations that will compliment farmer's efforts. The objectives of the study are:

- To examine the socio-economic characteristics of farmers in the area.

- To examine farmers awareness and perceptions of climate change

- To examine their on-farm responses and its effect on crop output

- To make policy recommendations based on the findings of the study.

Although the agricultural sector is dynamic and has demonstrated significant ability to adapt, many important related questions as regard adaptation of farmers to climate change and the effect on crop productivity remain unanswered, hence it is important to research these questions in order to facilitate and sustain crop productivity in rural area and to mitigate the problem of food insecurity. 


\section{Description of the study area}

\section{Research Methodology}

The study was carried out in Akinyele Local Government area of Ibadan, Oyo state.Ibadan the capital of Oyo State is located in the southwestern part of Nigeria; on longitude $3^{\circ} 54$ of the Greenwich median and latitude $7^{\circ} 54^{\prime}$ north of equator. The city is elevated at about 234 meters above the sea level and it is situated on gently rolling hills running in a northwest or southeast direction (Adebola and Olorin 2000). The 2006 census put the total population of Ibadan 2,550,593 while the average population density was 828 person per $\mathrm{km}^{2}$ (NPC,2006). Ibadan metropolis consists of eleven local government areas. Five of the local government areas are urban. These include; Ibadan north, Ibadan north east, Ibadan north west, Ibadan south, Ibadan south east, while the remaining six are rural. They are Akinyele, Lagelu, Egbeda, Onara, Oluyole, and Ido local government. Akinyele local government was established in 1976 with the administrative headquarters situated at Moniya. The major farming activity practiced in the area is crop faming; the main crops cultivated in the area are cassava, maize, coco-yam, vegetables, plantain, rice, groundnut, beans out of which maize, cassava, and coco-yam are the most important food crop grown because apart from sales they are also consumed by the household. The sales or prices of agricultural produce in this area are based on the season and market and the location of the individual farm.

\section{Sampling Technique and Data Collection}

The data was collected using simple random sampling techniques, and the villages from which survey respondents were drawn from are Oloje, Oloro, Oniyere, Amosun, Obatedo, Ikukoyi, Asalan, Iroko, Alabata, Aba seriki, Aba peri, Giwa, Dehindun, Ogunjimi, Akintunde, and Ijayi. The data were obtained through oral interviews with the aid of structured questionnaire. A total of hundred respondents were randomly drawn from whom information such as household socio-economic characteristics, years of farming experience and age of respondent, perception awareness and adaptation strategies etc. were obtained.

\section{Tools of data analysis}

The data obtained were analyzed using descriptive statistics and linear regression analysis. The descriptive analyses consist of tables used specifically to describe the socio-economic characteristics of the respondents. The processed data were presented mostly in tabular forms to give vivid comparative analysis needed to show observable trends. The multiple regression model was used to assess the effect of adaptation practices on crop output. Two sets of data were used in the construction of the regression models, the crop yield data was the dependent variable and the farming practices were the independent variables. The relationship between the dependent variable and independent variables is explained through this equation in form of

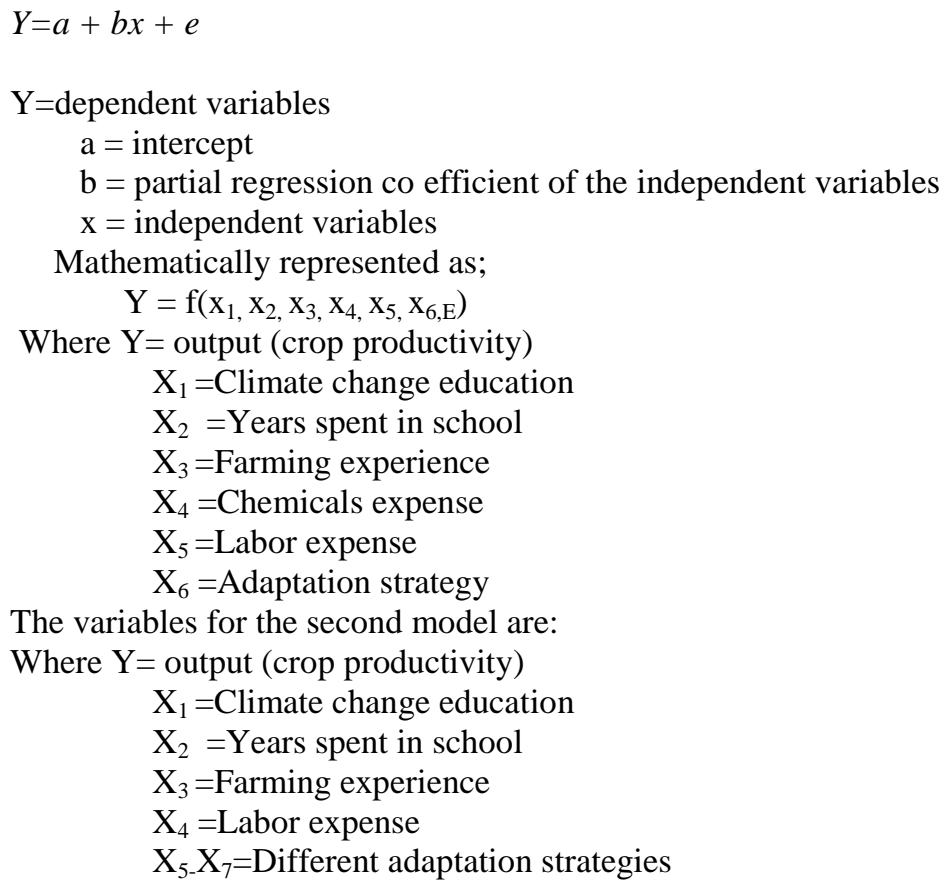




\section{Socio-economic Characterization of Farmers}

\section{Results}

Approximately 80 percent of the sampled farmers are men ranging between the ages of 25 years to 45 years. The modal age range was 50-59 years; but the average age was 47 years indicating that young people are not involved in farm activities in the area. Very few graduates were among the respondents; majority of them had exposure to primary or secondary school education while about 20 percent had no exposure to formal education. Informal education in the area includes quranic education (Table 1). Farming is considered to be a secondary activity by about 78 percent of the respondents; alternative income sources include trading, crafts etc. Additional information gathered showed that the female farmers were engaged in the processing of farm produce into consumable form. Land which is usually a limiting factor in agricultural production appears to be in abundance in the area, judging by the fact that shifting cultivation is still being practiced.Approximately 74 percent of the respondents have acres of land which belong to them. The abundance of land gives farmers access to it through purchase, renting and borrowing however inheritance is still the major source of land ownership.The modal class of land was 1-5 acres suggesting an average of 3 acres per farmer.

\section{Farmer's Awareness and Perception of Climate Change Observation in Output Variations}

The major change noticed in farm output was either an increase (72 percent) or a decrease (27 percent) in its quantity. The change was attributed to soil fertility, increase in the land area cultivated, farm management practices and some unique act of God among those who noticed that they had a bumper harvest. But those who noticed a decline attributed it to variations in the weather, pest and diseases while some were completely at a loss (Table 2).

\section{Farmers' Opinions of Climate Change}

Opinions of farmers on climate change vary; some (18.4 percent) did not express any views or show that they were aware of it while about 42 percent of the famers suggested that the evidence of climate change was a supernatural act. Crop destruction was associated with climate change effects by 26 percent of the respondents. Another 2 percent associate it with the scarcity of food items and the increase in food prices (Table 3).Majority of the farmers complained that the early maize planted in the survey year was totally destroyed due to the sudden decline of the rains.

\section{Farmers' Perceptions of Climate Change}

Farmer's perceptions of climate change were examined using 9 items on the likert scale. The results indicate that there is a fair understanding of climate change and the potential dangers it holds for farm output. Two points are however worrisome. The first is the fact that some seem to identify a positive impact of climate change on output and the second is the fact that 84 percent view the change and its consequences as a supernatural act (Table 4). Those who were either undecided or who disagreed where on the average about 20 percent; such people may not be motivated to take necessary actions.

\section{Farmer's on Farm Responses and Effects on Output \\ Farmers' Adaptation/Mitigation Strategies}

It was gathered that the major actions taking mostly by the farmers is the change in planting period, the farmers paid careful attention to the weather before planting. They waited till when they thought that the rains were consistent and were not likely to stop suddenly. Others simply cultivated what land or size of land that could be hand irrigated while others did not bother to make any attempt at coping with the situation (Table 5). Farmers generally used a mix of strategies in order to diversify the risk posed by climate change but focus primarily on one as presented in the table below. The fact that about 31 percent do not take any actions could indicate inability to do so, complacency or despair but no specific reasons were giving for this inaction.

\section{Effects of Awareness, Perception and Adaptation Variables on Output}

The variables chosen relates to what they perceive climate change to be, its possible effect on crops and the actions taken to correct or prevent such effects. The result shows that two out of the six independent variables are significant. The adaptation measures taken is significant at $1 \%$ and positive showing that it has a positive impact on the output produced. The perception of climate change as having a negative effect on output is significant at $5 \%$ indicating that this could drive them to take action to prevent it.

\section{Conclusion and Recommendation}


Climate plays a vital role in agriculture by setting limits to the production of crop. Farmers are obviously aware of climate change and its possible impact. They are able to develop their livelihood and adaptation strategies in a way that enables them to constantly cope with impact of climate change on crop production but the isolated effect of such practices on output is mixed and can be counter active. Water stress was noticed to be a main limitation to increased productivity. There is a need to investigate further to know the reasons for inaction among some farmers and how they could be helped. It is recommended that the government should provide a small scale irrigation project that will minimize this stress. There should be policy formulation considering crop farmers experiences with climate change, the policy should be a reliable one and effective measure of adaptation that need to be implemented must also be accessible.There is a needfor proper education and awareness on correct adaptation strategies as well as state support for proper adaptation of such techniques so that food supply will not be jeopardized in the long run.

\section{References}

[1]. Akpodiogaga.P and Odjugo.O (2010)General Overview of Climate Change Impacts In Nigeria InNigeria J Hum Ecol, 29(1): 47-55

[2]. Ayanwuyi, E Kuponiyi, F.A Ogunlade, Oyetoro JO (2010) Farmers Perception of Impact of Climate Changeson Food Crop Production in Ogbomosho Agricultural Zone of Oyo State, Nigeria in Global Journal of Human Social ScienceVol. 10 Issue 7 pg33

[3]. Easterling, W., P. Aggarwal, P. Batima, K. Brander, L. Erda, M. Howden, A. Kirilenko, J. Morton, J.-F. Soussana, S. Schmidhuber, and F. Tubiello, (2007) Food, fibre and forest products. In Climate Change 2007: Impacts, Adaptation and Vulnerability. Contribution of Working Group II to the Fourth Assessment Report of the Intergovernmental Panel on Climate Change. M.L. Parry, O.F. Canziani, J.P. Palutikof, P.J. van der Linden, and C.E. Hanson, Eds. Cambridge University Press, 273-313.

[4]. Hermann R. W. (2009) Climate Risk and Farming Systems in Rural Cameroon. Institute of Development and Agricultural Economics University of Hannover, Germany pp. 21-24.

[5]. Kurukulasuriya, P.Mendelsohn, R. Hassan, R, Benhin, J. Deressa, ...and Dinar, A. (2006) Will African agriculturesurvive climate change? World Bank Economic Review 20(3) 67-88.

[6]. Nigerian Environmental Study/Action Team (NEST) 2004. "Climate Change and Nigeria: AGuide for Policymakers." Ibadan, Nigeria.

[7]. Ole, M. Cheikh, M. Anette, R. and Awa, D. (2009) Farmers Perceptions of Climate Change and Agricultural Strategies in Rural Sahel. Journal of Environmental Management 4(3) 804-816.

[8]. Overseas Development Institute (ODI) (2007) Climate Change Agricultural Policy and Poverty Reduction how much do we know? Overseas Development Institute 2007 pp. 14-21

[9]. Parry, M.L., Canziani, O.F. Palutikof, J.P. van der Linden, P.J. and C.E. Hanson, Eds., (2007)“Climate Change: Impacts, Adaptation and Vulnerability. Contribution of Working Group IIto the Fourth Assessment Report of the Intergovernmental Panel on Climate Change" -Annex I., Cambridge University Press, Cambridge, UK, pp 976

[10]. United Nations Development Programme (UNDP) (2008) "Human Development Report: FightingClimate change: Human solidarity in a divided world 2007-2008." pp.7 http://hdr.undp.org/en/reports/global/hdr2007-2008/

Table 1: Farmer's Socio-Economic Characteristics

\begin{tabular}{|c|c|c|c|}
\hline Sex & Frequency & Percent & Cumulative percent \\
\hline Female & 17 & 17 & $\overline{17}$ \\
\hline Male & 82 & 83 & 100 \\
\hline Total & 99 & 100 & \\
\hline \multicolumn{4}{|l|}{ Age (Years) } \\
\hline $20-29$ & 3 & 3.0 & 3.0 \\
\hline $30-39$ & 21 & 21.2 & 24.2 \\
\hline $40-49$ & 26 & 26.3 & 50.5 \\
\hline $50-59$ & 31 & 31.3 & 81.8 \\
\hline $60-69$ & 15 & 15.2 & 97.0 \\
\hline $70-79$ & 3 & 3.0 & 100 \\
\hline Total & 99 & 100 & \\
\hline \multicolumn{4}{|l|}{ Education } \\
\hline Non-formal & 22 & 22.2 & 22.2 \\
\hline Primary & 38 & 38.4 & 60.6 \\
\hline Secondary & 24 & 24.2 & 84.8 \\
\hline Technical & 12 & 12.2 & 91.9 \\
\hline Graduate & 3 & 3.0 & 100 \\
\hline Total & 99 & 100 & \\
\hline \multicolumn{4}{|c|}{ Main Economic Activity } \\
\hline Farmers & 22 & 22.0 & 22.0 \\
\hline Trader & 21 & 21.0 & 43.0 \\
\hline Civil servant & 4 & 4.0 & 47.0 \\
\hline Artisan & 20 & 21.0 & 68.0 \\
\hline Others & 33 & 33 & 33 \\
\hline \multicolumn{4}{|l|}{ Land ownership } \\
\hline Owns land & 73 & 73,7 & 73.7 \\
\hline Does not Own land & 26 & 26.3 & 100 \\
\hline Total & 99 & 100 & \\
\hline \multicolumn{4}{|l|}{ Land size (acres) } \\
\hline $1-5$ & 85 & 85.9 & 85.9 \\
\hline$>5$ & 14 & 14.1 & 100 \\
\hline Total & 99 & 100 & \\
\hline
\end{tabular}


Source: Field Survey 2012

Table 2: Output Changes and Perceived Causes of The Change

\begin{tabular}{|c|c|c|c|}
\hline Item & Frequency & Percent & Cumulative \% \\
\hline \multicolumn{4}{|l|}{ Change Observed } \\
\hline Increased Output & 72 & 72.7 & 82.8 \\
\hline Decreased Output & 27 & 27.3 & 100 \\
\hline Total & 99 & 100 & \\
\hline \multicolumn{4}{|l|}{ Cause of Change } \\
\hline \multicolumn{4}{|l|}{ Increased Output } \\
\hline Farm Maintenance/ Management & 37 & 51.4 & 51.4 \\
\hline Gods help & 9 & 12.5 & 63.9 \\
\hline Nature of the soil/land & 16 & 22.2 & 86.1 \\
\hline Land area cultivated & 10 & 13.9 & 100 \\
\hline Total & 72 & 100 & \\
\hline \multicolumn{4}{|l|}{ Decreased Output } \\
\hline No Idea & 12 & 44.4 & 44.4 \\
\hline Pest and disease & 1 & 3.7 & 48.1 \\
\hline Weather & 14 & 51.9 & 100 \\
\hline Total & 27 & 100 & \\
\hline
\end{tabular}

Source: Field Survey 2012

Table 3: Opinion/Awareness of Climate Change

\begin{tabular}{lrrr}
\hline Personal opinions & Frequency & Percentage & Cumulative Percentage \\
\hline No opinion & 18 & 18.4 & 18.4 \\
Supernatural act & 41 & 42.0 & 60.2 \\
Crop Destruction & 24 & 24.5 & 84.7 \\
Scarcity and High Food Prices & 2 & 2.0 & 100 \\
Total & $\mathbf{9 9}$ & $\mathbf{1 0 0}$ & \\
\hline
\end{tabular}

Source: Field Survey 2012

Table 4: Farmer's Perception of Climate Change

\begin{tabular}{|c|c|c|c|c|c|c|c|}
\hline Item & $\begin{array}{l}\text { Strongly } \\
(\%)\end{array}$ & Agree & $\begin{array}{l}\text { Agree } \\
(\%)\end{array}$ & $\begin{array}{l}\text { Undecided } \\
(\%)\end{array}$ & $\begin{array}{l}\text { Disagree } \\
(\%)\end{array}$ & $\begin{array}{l}\text { Strongly } \\
(\%)\end{array}$ & Disagree \\
\hline Climate change refers to change in temperature & & 25.4 & 51.4 & 15.2 & 7.0 & & 1.0 \\
\hline $\begin{array}{l}\text { Climate change refers to temperature and rainfall } \\
\text { change }\end{array}$ & & 37.8 & 46.9 & 10.2 & 5.1 & & 0.0 \\
\hline Climate change affects production pattern & & 45.8 & 44.0 & 2.0 & 5.1 & & 3.1 \\
\hline Climate change has a negative effect on output & & 54.1 & 31.5 & 10.2 & 3.1 & & 1.0 \\
\hline Climate change has impact on soil fertility & & 54.1 & 31.5 & 10.2 & 3.1 & & 1.0 \\
\hline Climate change leads to flooding & & 45.9 & 34.7 & 9.2 & 9.2 & & 1.0 \\
\hline Climate change leads to pest and diseases & & 72.1 & 16.5 & 8.3 & 0.0 & & 3.1 \\
\hline Climate change impact production positively & & 26.5 & 55.2 & 11.2 & 6.1 & & 1.0 \\
\hline Climate change is a spiritual problem & & 67.4 & 16.3 & 8.2 & 7.1 & & 1.0 \\
\hline
\end{tabular}

Source: Field Survey, 2012

Table 5: Primary Actions Taken by Farmers to Reduce the Effect of climate Change

\begin{tabular}{lrrr}
\hline Item & Frequency & Percentage & \multicolumn{2}{c}{$\begin{array}{c}\text { Cumulative } \\
\text { Percentage }\end{array}$} \\
\hline No Response & 31 & 31.6 & 31.6 \\
Changed Planting Period & 36 & 36.9 & 68.4 \\
Shifted to another land & 9 & 9.2 & 77.6 \\
Use of Fertilizer & 8 & 8.2 & 85.7 \\
Crop rotation & 1 & 1.0 & 86.7 \\
Mixed cropping & 3 & 3.1 & 89.8 \\
Increased Heap height & 1 & 1.0 & 100.8 \\
Wetting & 9 & 9.2 & \\
Total & $\mathbf{9 9}$ & $\mathbf{1 0 0}$ & \\
\hline
\end{tabular}

Source: Field Survey, 2012 
Table 6a: Regression Model Result

\begin{tabular}{lllll}
\hline Model & Coefficient & Std. error & t & Sig. \\
\hline Constant & & 3.736 & 1.318 & .192 \\
Climate Change Education & -.206 & .085 & -1.907 & .061 \\
Years Spent in School & -.018 & .124 & -.159 & .874 \\
Farming Experience & .206 & .032 & 1.784 & .079 \\
Chemicals Expense & .068 & .001 & .604 & .548 \\
Labor Expense & -.384 & .001 & -3.516 & .001 \\
$\quad$ Adaptation strategy & .226 & .042 & 2.038 & .046 \\
$\mathbf{R}^{2}$ & & & & 0.30 \\
Durbin-Watson & & & & 1.85 \\
F-Statistic & & & & 0.001 \\
Dependent Variable: Change in Output & & & & \\
\hline
\end{tabular}

Table 6b: Regression Model Result

\begin{tabular}{|c|c|c|c|c|}
\hline Model & Coefficient & Std. Error & $\mathrm{t}$ & Sig. \\
\hline Constant & & 3.628 & 1.664 & .101 \\
\hline Climate Change Education & -.275 & .083 & -2.603 & .012 \\
\hline Years Spent in School & -.068 & .121 & -.623 & .536 \\
\hline Farming Experience & .228 & .032 & 2.013 & .049 \\
\hline Labor Expense & -.390 & .001 & -3.742 & .001 \\
\hline Adaptation Strategy I (Planting date \& shift) & -.324 & .249 & -1.943 & .057 \\
\hline Adaptation Strategy II (PD, shift \& fertilize) & .353 & .275 & 2.210 & .031 \\
\hline Adaptation Strategy III (PD, shift, fertilize \& wet) & .248 & .118 & 2.205 & .031 \\
\hline $\mathrm{R}^{2}$ & & & 4.36 & 0.37 \\
\hline Durbin-Watson & & & & 1.89 \\
\hline F-Statistic & & & & 0.001 \\
\hline Dependent Variable: Change in Output & & & & \\
\hline
\end{tabular}

